\title{
Exergy performance of different space heating systems: A theoretical study
}

\author{
Kazanci, Ongun Berk; Shukuya, Masanori; Olesen, Bjarne W.
}

Published in:

Building and Environment

Link to article, DOI:

10.1016/j.buildenv.2016.01.025

Publication date:

2016

Document Version

Peer reviewed version

Link back to DTU Orbit

Citation (APA):

Kazanci, O. B., Shukuya, M., \& Olesen, B. W. (2016). Exergy performance of different space heating systems: A theoretical study. Building and Environment, 99, 119-129. https://doi.org/10.1016/j.buildenv.2016.01.025

\section{General rights}

Copyright and moral rights for the publications made accessible in the public portal are retained by the authors and/or other copyright owners and it is a condition of accessing publications that users recognise and abide by the legal requirements associated with these rights.

- Users may download and print one copy of any publication from the public portal for the purpose of private study or research.

- You may not further distribute the material or use it for any profit-making activity or commercial gain

- You may freely distribute the URL identifying the publication in the public portal 


\title{
Exergy performance of different space heating systems: A
}

\section{theoretical study}

* Corresponding author. Tel.: +4550281327, Fax: +4545932166, e-mail address: onka@ byg.dtu.dk

\begin{abstract}
Three space heating systems (floor heating with different floor covering resistances, radiator heating with different working temperatures, warm-air heating with and without heat recovery) were compared using a natural gas fired condensing boiler as the heat source. For the floor heating systems, the effects of floor covering resistance on the whole system performance were studied using two heat sources; a natural gas fired condensing boiler and an air-source heat pump. The heating systems were also compared in terms of auxiliary exergy use for pumps and fans.
\end{abstract}

The low temperature floor heating system performed better than other systems in terms of exergy demand. The use of boiler as a heat source for a low-exergy floor heating system creates a mismatch in the exergy supply and demand. Although an air-source heat pump could be a better heat source, this depends on the origin of the 
electricity supplied to the heat pump. The coefficient of performance (COP) of the heat pump has a critical value ( 2.57 in this study); it is beneficial to use a heat pump instead of a boiler only when the COP is above this critical value.

The floor covering resistance should be kept to a minimum, in order not to hinder the performance of the floor heating and the whole system. The exergy input to auxiliary components plays a significant role in the overall exergy performance of systems, and its effects become even more significant for low temperature heating systems.

\section{Keywords}

floor heating; floor covering resistance; radiator heating; warm-air heating; boiler; heat pump 


\section{Introduction}

The choice of space heating system (terminal unit, heat source, etc.) in buildings has important effects on energy and exergy demands, occupant thermal comfort, and on global environment. Although heating load calculations and energy-wise analyses are necessary for system dimensioning, they are not sufficient since energy analyses cannot quantitatively clarify the effects of working temperature levels. Several studies have documented that energy analyses alone are not sufficient to completely understand energy use [1], [2], [3]. Exergy analysis can be used for this purpose. Exergy has a wide application range in engineering systems, including heating, cooling, ventilation systems and built environment [4], [5], [6], [7], [8]. Recently, exergy analysis has also been used to evaluate the operation and control of heating, ventilation and air conditioning (HVAC) systems in buildings [9], [10], [11].

Gonçalves et al. [12] compared energy and exergy performances of eight space heating alternatives under different climatic conditions. Zhou and Gong [13] studied the whole chain of exergy flows for a building heating and cooling system by hourly varying the reference state. Balta et al. [14], Lohani [15], and Lohani and Schmidt [16] studied different heat sources for building heating applications. Zmeureanu and $\mathrm{Wu}$ [17] studied the energy and exergy performance of residential heating systems. Schmidt [18] compared different heat sources and heat emission systems (radiator and floor heating), and concluded that the floor heating system performs close to ideal conditions (real exergetic demand of the zone). This is mainly due to the low temperature heating possibility of water-based radiant floor heating systems. Kilkis [19] studied the possibilities of coupling radiant floors to air-source heat pumps, and showed that it is possible to eliminate the supplementary boilers, and this coupling can increase the coefficient of performance (COP) of heat pumps.

The surface covering of a radiant floor heating system could be a subjective choice due to interior design of spaces, and this could have important effects on the performance of the floor heating system, and on the whole space heating system. Simmonds et al. [20], and Sattari and Farhanieh [21] studied the effects of floor covering 
on radiant floors. After a parametric study, Sattari and Farhanieh [21] concluded that the type and thickness of the floor covering are the most important parameters in the design of radiant heating systems.

This study compares the exergy performance of different space heating systems, using a single-family house as a case study. The house was considered to be conditioned with different space heating systems and the exergy performances of these systems were compared. The systems were floor heating with different floor covering resistances, radiator heating with different working temperatures, warm-air heating with and without heat recovery. These systems were also compared in terms of auxiliary exergy used for pumps and fans. The relative benefits of applying heat recovery in the ventilation system were also studied.

For the floor heating systems, the effects of floor covering resistance on the whole system performance was studied, and two heat sources were compared; a natural gas fired condensing boiler and an air-source heat pump.

\section{Description of the case studies and determination of the key parameters}

\subsection{Construction details and description of the house}

The house considered in this study was a detached, one-story, single-family house with a floor area of $66.2 \mathrm{~m}^{2}$ and a conditioned volume of $213 \mathrm{~m}^{3}$. The house was located in Denmark. It was constructed from wooden elements. The house was insulated with a combination of $200 \mathrm{~mm}$ mineral wool and $80 \mathrm{~mm}$ compressed stone wool fibers.

Inside the house, there was a single space combining different functions. The glazing façades were partly shaded by the roof overhangs. The largest glazing façade was oriented to the North with a $19^{\circ}$ turn towards the West. Fig. 1 shows the exterior and interior views of the house. The surface areas and thermal properties of the envelope are given in Table 1. 

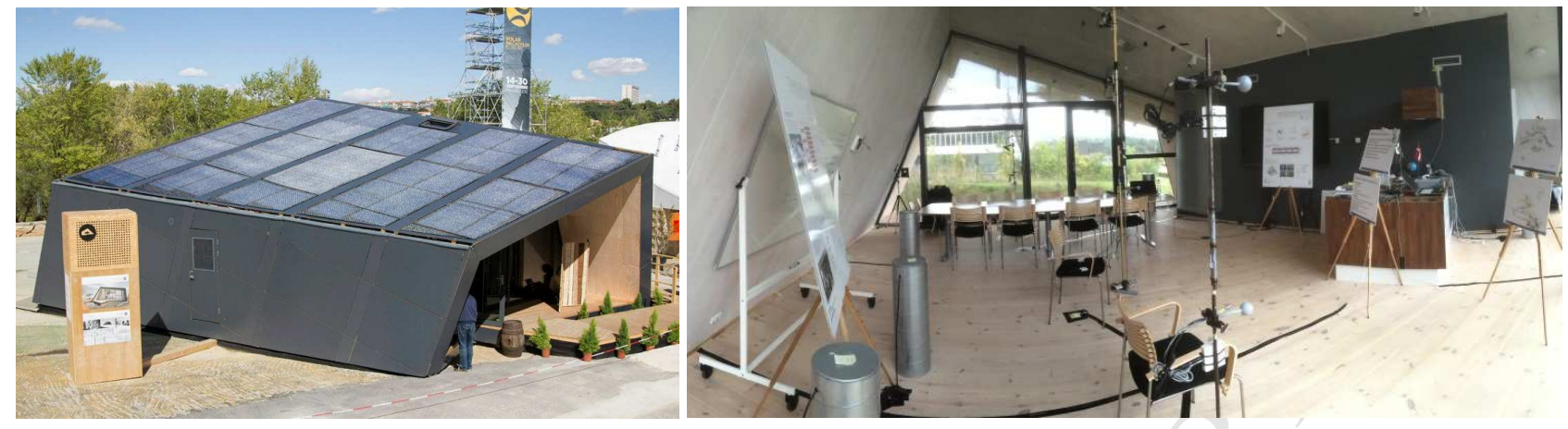

Fig. 1. Exterior (seen from South-West) and interior views of the house

Table 1. Thermal properties of the envelope

\begin{tabular}{|c|c|c|c|c|c|c|}
\hline & North & South & East & West & Floor & Ceiling \\
\hline Walls, Area, $\left[\mathrm{m}^{2}\right]$ & - & - & 37.2 & 19.3 & 66.2 & 53 \\
\hline Walls, U-value, $\left[\mathrm{W} / \mathrm{m}^{2} \mathbf{K}\right]$ & - & - & 0.09 & 0.09 & 0.09 & 0.09 \\
\hline Windows, Area, $\left[\mathrm{m}^{2}\right]$ & 36.7 & 21.8 & $-\quad$ & - & - & 0.74 \\
\hline Windows, U-value, $\left[\mathrm{W} / \mathrm{m}^{2} \mathrm{~K}\right]$ & 1.04 & 1.04 & - & - & - & 1.04 \\
\hline
\end{tabular}

2.2. Details of the heating, cooling, and ventilation systems in the house

The sensible heating and cooling of the house relied on the low temperature heating and high temperature cooling principle by the hydronic radiant floor. The floor heating system was a dry radiant system, consisting of a piping grid installed in the wooden layer. The details of the floor system were: chipboard elements, with aluminum heat conducting profiles (thickness $0.3 \mathrm{~mm}$ and length $0.17 \mathrm{~m}$ ), PE-X pipe, $17 \times 2.0 \mathrm{~mm}$. Pipe spacing was $0.2 \mathrm{~m}$. The available floor area for the embedded pipe system installation was $45 \mathrm{~m}^{2}$, which is $68 \%$ of the total floor area. Fig. 2 shows the details of the floor structure.

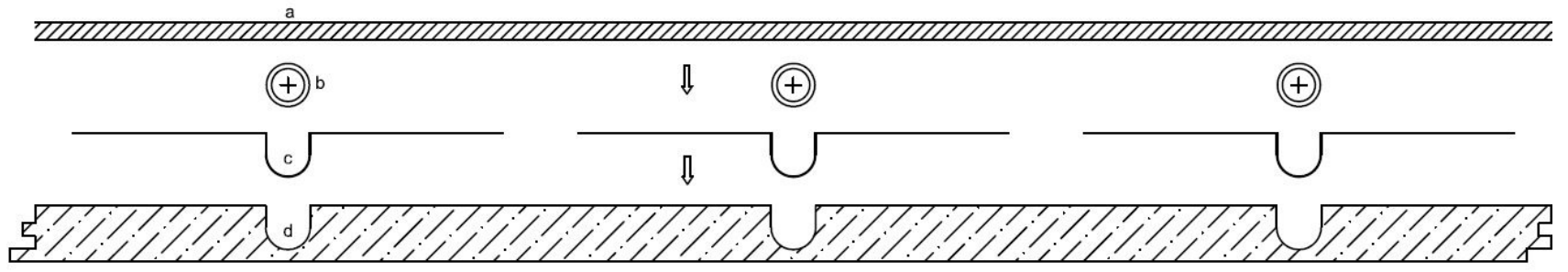

Fig. 2. a) Floor covering b) Pipe, $17 \times 2.0 \mathrm{~mm}$ c) Heat distribution plate, $0.3 \mathrm{~mm}$, d) Under-floor plate, $22 \mathrm{~mm}$ 
The heat source and sink of the house for space heating and cooling was outdoor air, using a reversible air-tobrine heat pump. The minimum and maximum cooling capacities and the nominal power input in the cooling mode were 4.01, 7.1, and $2.95 \mathrm{~kW}$, respectively. The minimum and maximum heating capacities and the nominal power input in the heating mode were $4.09,7.75$, and $2.83 \mathrm{~kW}$, respectively.

A flat-plate heat exchanger was installed between the hydronic radiant system of the house and the air-to-brine heat pump. The pipes between the heat exchanger and the heat pump were filled with an anti-freeze mixture (40\% ethylene glycol) to avoid frost damage during winter.

A mixing station which linked the radiant system with the heat source and sink, and the controller of the radiant system controlled the flow and the supply temperature to the radiant system. The operation of the radiant system was based on the operative temperature set-point that was adjusted on a room thermostat and on the relative humidity inside the house to avoid condensation during summer.

The house was ventilated mechanically by an air handling unit (AHU), by which only the fresh air taken into the house was heated or cooled since the main sensible heating and cooling terminal was the radiant system. This also made it possible to have lower air flow rates compared to a system where space heating and cooling is mainly obtained by an air system [22]. The design ventilation rate was 0.5 ach [23].

There were two options for heat recovery in the AHU. One was obtained by means of a cross-flow heat exchanger with the heat recovery efficiency of $85 \%$ (sensible heat) and with a by-pass route. The other was achieved by means of a reversible air-to-water heat pump that was coupled to the domestic hot water tank. The former is the passive and the latter is the active heat recovery, respectively. The AHU could supply fresh air at a flow rate of up to $320 \mathrm{~m}^{3} / \mathrm{h}(1.5 \mathrm{ach})$ at $100 \mathrm{~Pa}$. Further details of the components and the system can be found in [24], [25], [26]. 


\subsection{Determination of the design heating load}

The dimensioning of the systems in the house was based on the design outdoor condition, which in Denmark is an outdoor air temperature of $-12^{\circ} \mathrm{C}$ [27], though in the theoretical analyses in this paper the outdoor temperature was taken to be $-5^{\circ} \mathrm{C}$, which is a more typical winter temperature. Previous experiments comparing the performance of different heating systems in a room had also assumed an outdoor temperature of $-5^{\circ} \mathrm{C}$ [28].

For all cases, the indoor temperature was considered to be $20^{\circ} \mathrm{C}$ (air temperature and mean radiant temperature).

The calculations were carried out under steady-state conditions. No solar heat gains were considered. The internal heat gain was considered to be constant and $4.5 \mathrm{~W} / \mathrm{m}^{2}$, which represents two persons at 1.2 met and other household equipment. For the given heat recovery efficiency in the AHU, the supply air temperature after the heat recovery was $16.3^{\circ} \mathrm{C}$. The parameters used in the load calculations and the resulting space heating loads are given in Table 2.

Table 2. Parameters used in the load calculations and resulting space heating loads

\begin{tabular}{|c|c|}
\hline Indoor temperature $\left[{ }^{\circ} \mathbf{C}\right]$ & 20 \\
\hline Outdoor temperature $\left[{ }^{\circ} \mathbf{C}\right]$ & -5 \\
\hline Internal heat gain $\left[\mathrm{W} / \mathrm{m}^{2}\right]$ & 4.5 \\
\hline Ventilation rate [ach] & 0.5 \\
\hline Infiltration rate [ach] & 0.2 \\
\hline $\begin{array}{c}\text { Heating load - envelope (no ventilation), total }[\mathrm{W}] \text { and } \\
\text { per floor area }\left[\mathrm{W} / \mathrm{m}^{2}\right]\end{array}$ & $2048 / 30.9$ \\
\hline $\begin{array}{l}\text { Heating load - envelope and heat recovery ventilation, } \\
\text { total }[\mathrm{W}] \text { and per floor area }\left[\mathrm{W} / \mathrm{m}^{2}\right]^{*}\end{array}$ & $2180 / 32.9$ \\
\hline
\end{tabular}




\subsection{Determination of the key parameters}

Following the calculation of the space heating load, the parameters of the different space heating strategies necessary for the present exergy analyses were determined. It was assumed that the heating demand of the house was addressed with different heating systems; floor heating, radiator heating, and warm-air heating. The following assumptions were made during the calculations:

- In the actual house there was a heat exchanger between the radiant system and the heat pump, but for the calculations this heat exchanger was neglected and it was assumed that the water in the embedded pipes circulated directly through the boiler or the condenser of the heat pump. The same assumption applied to the radiator heating cases.

- The supply air was $100 \%$ outdoor air (no recirculation), and the indoor air was assumed to be fully mixed.

- The active heat recovery was not considered and the AHU was considered to be working in the passive heat recovery mode, as described in 2.2 .

- It was assumed that there was no heat loss from the floor heating system, radiators, pipes and ducts to the outdoors.

The schematic drawings of the analyzed heating systems are given in Fig. 3. 
a)

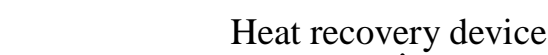

Outdoor air

Exhaust fan

Heat recovery device

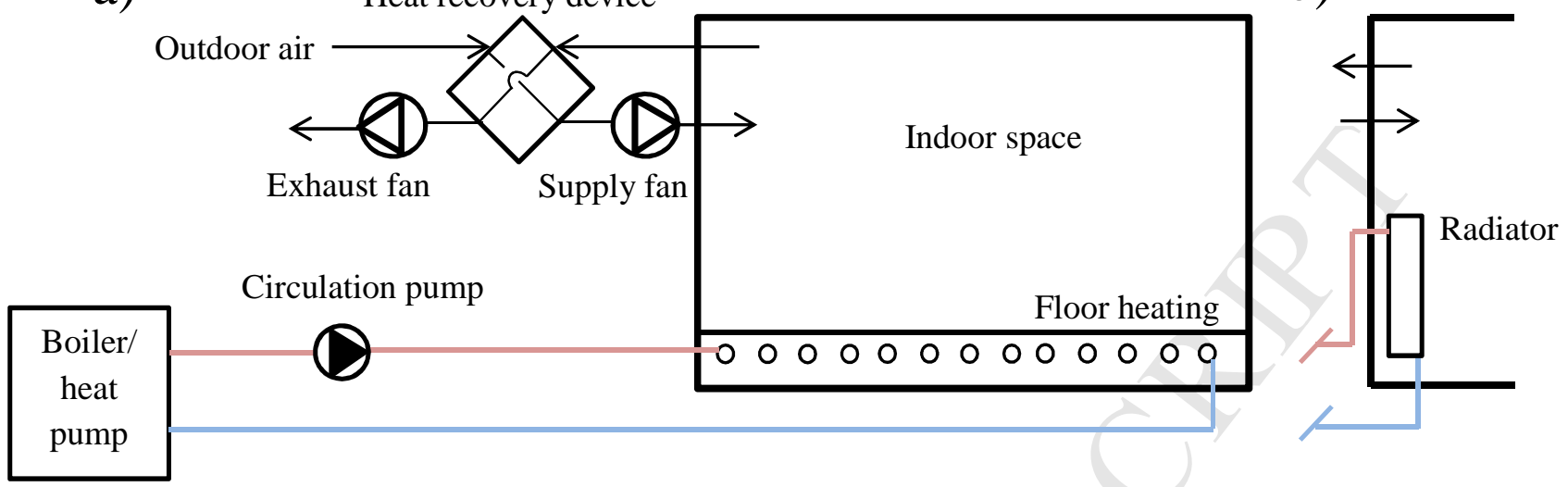

c)

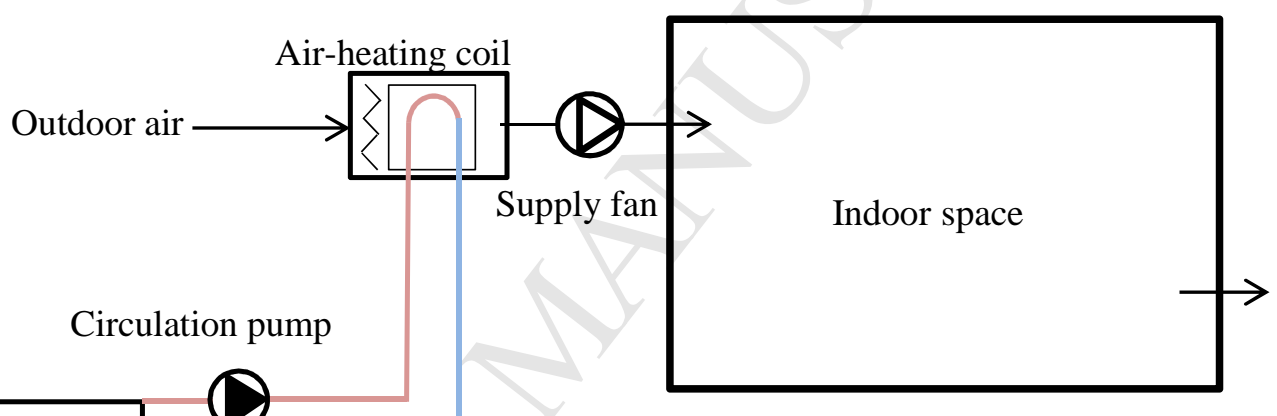

Boiler

d)

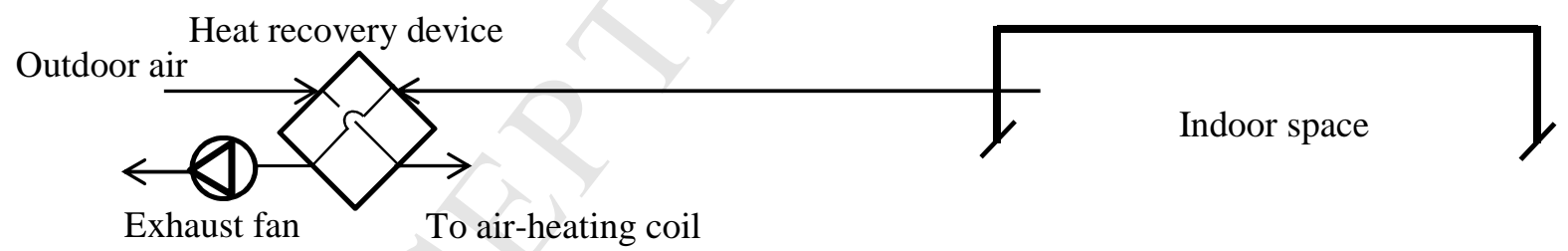

Fig. 3. Schematic drawings of the analyzed heating systems: a) Floor heating b) Radiator heating c) Warm-air heating without heat recovery d) Warm-air heating with heat recovery

\subsubsection{Floor heating with different floor covering resistances}

The effect of the floor covering resistance on the whole system performance of floor heating was studied through different floor covering resistances. The thermal resistances considered were $0.05 \mathrm{~m}^{2} \mathrm{~K} / \mathrm{W}, 0.09 \mathrm{~m}^{2} \mathrm{~K} / \mathrm{W}$ (actual value), and $0.15 \mathrm{~m}^{2} \mathrm{~K} / \mathrm{W}$, following the most common values given in respective standards [29]. The same floor 
covering material was used (thermal conductivity is $0.13 \mathrm{~W} / \mathrm{mK}$, wooden floor covering), but with $0.0065 \mathrm{~m}$, $0.012 \mathrm{~m}$ and $0.0195 \mathrm{~m}$ thickness, respectively. For each resistance value, a new water supply temperature was calculated.

The load calculations showed that a specific heat output of $48.4 \mathrm{~W} / \mathrm{m}^{2}$-floor heating area with an average floor surface temperature of $24.7^{\circ} \mathrm{C}$ was required to meet the necessary space heating demand. The heat output and surface temperatures were calculated according to [29] and [30]. The surface temperatures of the floor heating systems were the same for all cases, and this was achieved by adjusting the supply and return temperatures to the floor heating system. For all cases, the temperature drop between the supply and return water in the radiant system was $4 \mathrm{~K}$. The mass flow rate was calculated based on EN 1264-3:2009 [31] and was found to be $469 \mathrm{~kg} / \mathrm{h}$. A summary of the floor heating cases is given in Table 3.

Table 3. Summary of the floor heating cases

\begin{tabular}{lcccc}
\hline Case name & $\begin{array}{c}\text { Floor covering resistance } \\
{\left[\mathbf{m}^{\mathbf{2}} \mathbf{K} / \mathbf{W}\right]}\end{array}$ & $\begin{array}{c}\text { Supply } \\
\text { temperature }\left[{ }^{\circ} \mathbf{C}\right]\end{array}$ & $\begin{array}{c}\text { Return } \\
\left.\text { temperature [ }{ }^{\circ} \mathbf{C}\right]\end{array}$ & $\begin{array}{c}\text { Heat pump } \\
\mathbf{C O P}[-]\end{array}$ \\
\hline FH_LoRes & 0.05 & 33 & 29 & 2.63 \\
FH_MRes & 0.09 & 35.8 & 31.8 & 2.48 \\
FH_HiRes & 0.15 & 39.8 & 35.8 & 2.31 \\
\hline
\end{tabular}

\subsubsection{Radiator heating with different working temperatures}

The assumed radiator type was a double panel steel radiator with extended surface (fins) [32]. Four sets of working temperatures were assumed according to prEN 15316-2:2014 [33]: 45/35, 55/45, 70/55, and 90/70 (supply/return water temperature in ${ }^{\circ} \mathrm{C}$ ).

The required flow rates in the radiators were determined according to the space heating load and the temperature difference between the supply and return water temperatures to and from the radiator. 
The average surface temperatures of the radiators were assumed to be $0.3^{\circ} \mathrm{C}$ lower than the simple average value of inlet and outlet water temperatures. This value was determined so that not only the energy balance but also the entropy and exergy balance equations were satisfied. Table 4 summarizes the radiator heating cases.

Table 4. Summary of the radiator heating cases

\begin{tabular}{ccccc}
\hline Case name & $\begin{array}{c}\text { Supply temperature } \\
{\left[{ }^{\circ} \mathbf{C}\right]}\end{array}$ & $\begin{array}{c}\text { Return temperature } \\
{\left[{ }^{\circ} \mathbf{C}\right]}\end{array}$ & $\begin{array}{c}\text { Surface temperature } \\
{\left[{ }^{\circ} \mathbf{C}\right]}\end{array}$ & Mass flow rate $[\mathbf{k g} / \mathbf{h}]$ \\
\hline R_45 & 45 & 35 & 39.7 & 188 \\
R_55 & 55 & 45 & 49.7 & 188 \\
R_70 & 70 & 55 & 62.2 & 125 \\
R_90 & 90 & 70 & 79.7 & 94 \\
\hline
\end{tabular}

2.4.3. Warm-air heating with and without heat recovery

In addition to the water-based heating systems, an air-based heating system was also analyzed and two cases, without and with a heat recovery device, as shown in Fig. 3 c) and d), were studied.

The supply air temperature to the space was limited to $35^{\circ} \mathrm{C}$ [27]. The necessary heating rate needed for bringing the outdoor air at $-5^{\circ} \mathrm{C}$ to the supply air temperature of $35^{\circ} \mathrm{C}$ was $5460 \mathrm{~W}$ when there was no heat recovery, and it decreased to $2559 \mathrm{~W}$ with heat recovery. The necessary heat was supplied to the air by an air-heating coil which was connected to a boiler. The supply and return water temperatures to the air-heating coil were $50^{\circ} \mathrm{C}$ and $39^{\circ} \mathrm{C}$, respectively [32].

The necessary air flow rate $(1.9 \mathrm{ach})$ and the water flow rates in the air-heating coil are given in Table 5 together with a summary of the warm-air heating cases.

Table 5. Summary of the warm-air heating cases

\begin{tabular}{|c|c|c|c|c|c|}
\hline Case name & $\begin{array}{c}\text { Intake air } \\
\text { temperature }\left[{ }^{\circ} \mathbf{C}\right]\end{array}$ & $\begin{array}{c}\text { Air temperature } \\
\text { after } \mathrm{HR}\left[{ }^{\circ} \mathbf{C}\right]\end{array}$ & $\begin{array}{c}\text { Supply air } \\
\text { temperature }\left[{ }^{\circ} \mathbf{C}\right]\end{array}$ & $\begin{array}{c}\text { Air flow rate } \\
{\left[\mathrm{m}^{3} / \mathrm{h}\right]}\end{array}$ & $\begin{array}{l}\text { Mass flow rate in air- } \\
\text { heating coil [kg/h] }\end{array}$ \\
\hline WAH_NoHR & -5 & - & 35 & 410 & 428 \\
\hline WAH_HR & -5 & 16.3 & 35 & 410 & 201 \\
\hline
\end{tabular}




\subsubsection{Fan and pump powers}

The power to be supplied to fans and pumps that circulate the heat transfer medium in pipes or in ducts was determined as follows.

For the floor heating and radiator heating cases, it was assumed that there is a pump which circulates the water between the boiler or heat pump and the floor loops and radiators. Additionally, two identical fans (supply and exhaust) were considered in the AHU. For the warm-air heating cases, a pump, which circulates the water between the boiler and the air-heating coil, was assumed. For the case without heat recovery, only a supply fan providing the necessary air flow to the indoors was assumed, while for the case with heat recovery, two identical fans were assumed.

The pump power for different cases was obtained from the pump specifications (performance curve of the installed pump) as a function of the water flow rate and the required pressure increase, assuming the pump actually installed in the house.

The measurements from the house were used to obtain the fan powers. The measurements from the house showed that the AHU was using $67.9 \mathrm{~W}$ with a ventilation rate of $0.5 \mathrm{ach}\left(105 \mathrm{~m}^{3} / \mathrm{h}\right)$ [26], which corresponds to a total specific fan power (SFP) of $2331 \mathrm{~J} / \mathrm{m}^{3}$ for two fans, and for one fan it corresponds to $1166 \mathrm{~J} / \mathrm{m}^{3}$. This SFP value is in SFP 3 category according to EN 13779:2007 [34].

Assuming that the fans for the warm-air heating cases are also in SFP 3 category $\left(1200 \mathrm{~J} / \mathrm{m}^{3}\right)$, the fan powers were calculated as a function of the air-flow rates.

Table 6 summarizes the pump and fan powers for different cases. 
Table 6. Summary of the pump and fan powers for different heating cases

\begin{tabular}{cccc}
\hline & Eump $_{\text {pum] }}$ & E $_{\text {fans }}$ [W] & $\mathbf{E}_{\text {total }}$ [W] \\
\hline FH_LoRes, FH_MRes, FH_HiRes & 27.5 & 67.9 & 95.4 \\
R_45, R_55 & 24.5 & 67.9 & 92.4 \\
R_70 & 23 & 67.9 & 90.9 \\
R_90 & 22 & 67.9 & 89.9 \\
WAH_NoHR & 27 & 136.5 & 163.5 \\
WAH_HR & 25 & 273 & 298 \\
\hline
\end{tabular}

\subsubsection{Heat and power generation}

For the first part of the analyses, it was assumed that the heat generation for space heating for all cases was through a natural gas fired condensing boiler with an efficiency of $90 \%$ [5], [35]. The ratio of chemical exergy to the higher heating value of natural gas was taken as 0.93 [5].

In the second part of the analyses, it was assumed that the floor heating was coupled to an air-to-water heat pump. The COP of the heat pump was obtained from the manufacturer's datasheets as a function of the outdoor air temperature and the temperature of the water leaving the condenser (assumed equal to the supply water temperature to the floor loops).

It was assumed that the electricity provided to the heat pump, pumps, and fans was generated in a remote, natural gas fired power plant. The conversion efficiency at the power plant, transmission and distribution efficiencies combined was assumed to be 0.35 [5].

\section{Basic definitions of exergy and calculation methodology}

\subsection{Basic definitions}

For any system in consideration, it is possible to obtain the exergy balance equation from energy and entropy balance equations. In general form, exergy balance equation is obtained as follows [5]:

The energy and entropy balance equations for a system are 
$[$ Energy input $]=[$ Energy stored $]+[$ Energy output $]$

$[$ Entropy input $]+[$ Entropy generated $]=[$ Entropy stored $]+[$ Entropy output $]$

In its general form, exergy $=$ energy - entropy $\cdot T_{0}$. Therefore it is possible to obtain the exergy balance equation as Eq. (1) - Eq. (2) $\cdot \mathrm{T}_{\mathrm{o}}$.

$[$ Exergy input $]-[$ Exergy consumed $]=[$ Exergy stored $]+[$ Exergy output $]$

Where $[$ Exergy consumed $]=[$ Entropy generated $] \cdot \mathrm{T}_{\mathrm{o}}$, and $\mathrm{T}_{\mathrm{o}}$ is the environmental (reference) temperature $[\mathrm{K}]$, where the system and its components are situated in. The storage terms in Eqs. (1), (2), and (3) disappear under steady-state conditions.

Eqs. (1), (2), and (3) indicate that every system consumes a part of the supplied exergy and in the meanwhile entropy is generated. This applies for heating and cooling systems in buildings as well.

\subsection{Heating exergy load}

The heating exergy load [1] is the necessary load that the heating system has to address. It is defined as

$X_{\text {heating }}=Q_{\text {heating }}\left(1-\frac{T_{o}}{T_{i}}\right)$

Where $\mathrm{X}_{\text {heating }}$ is the heating exergy load [W], Qheating is the space heating load [W], $\mathrm{T}_{\mathrm{o}}$ is outdoor

(environmental) temperature $[\mathrm{K}]$, and $\mathrm{T}_{\mathrm{i}}$ is the operative temperature $[\mathrm{K}]$.

\subsection{Exergy supplied to indoors}

The exergy supplied to the indoor space from floor heating, from radiators, and from warm air are given in Eqs. (5), (6), and (7), respectively: 
$X_{F H, \text { out }}=Q_{\text {heating }}\left(1-\frac{T_{o}}{T_{S, F H}}\right)$

$X_{R, \text { out }}=Q_{\text {heating }}\left(1-\frac{T_{o}}{T_{S, R}}\right)$

$\Delta X_{W A H, o u t}=V_{s a} c_{a} \rho_{a}\left\{\left(T_{s a}-T_{i}\right)-T_{o} \ln \frac{T_{s a}}{T_{i}}\right\}$

Where $\mathrm{X}_{\mathrm{FH}, \text { out }}$ is the exergy supplied from floor heating to the indoor space [W], $\mathrm{T}_{\mathrm{S}, \mathrm{FH}}$ is the average

temperature of the heated floor surface $[\mathrm{K}], \mathrm{X}_{\mathrm{R}, \text { out }}$ is the exergy supplied from radiator to the indoor space $[\mathrm{W}]$,

$T_{S, R}$ is the average surface temperature of the radiator $[K], \Delta \mathrm{X}_{\mathrm{WAH}, \text { out }}$ is the net exergy supplied through warm air to the indoor space (the difference in the exergy flows between the supply air and the indoor air) [W], $\mathrm{V}_{\mathrm{sa}}$ is the volumetric flow rate of supply air $\left[\mathrm{m}^{3} / \mathrm{s}\right], \mathrm{c}_{\mathrm{a}}$ is the specific heat capacity of air $[\mathrm{J} / \mathrm{kgK}], \rho_{\mathrm{a}}$ is the density of air $\left[\mathrm{kg} / \mathrm{m}^{3}\right]$, and $\mathrm{T}_{\mathrm{sa}}$ is the temperature of the supply air $[\mathrm{K}]$.

Exergy consumed in the indoor space is the difference between the exergy supplied indoors and the heating exergy load.

3.4. Exergy consumption in the floor, radiator, air-heating coil, and heat recovery device

The exergy consumptions in the floor structure and in the radiator are possible to obtain from the exergy balance for these terminal units as

$\Delta X_{W}-X_{c}=X_{\text {out }}$

$\Delta X_{w}=X_{w, \text { supply }}-X_{w, r e t u r n}$

Where $\Delta X_{\mathrm{w}}$ is the difference between the rate of exergy of the supply and return water (net exergy input) [W],

$\mathrm{X}_{\mathrm{w}, \text { supply }}$ is the exergy of the supply water flow (into the floor or radiator) [W], $\mathrm{X}_{\mathrm{w}, \text { return }}$ is the exergy of the 
return water flow (from the floor or radiator) $[\mathrm{W}], \mathrm{X}_{\mathrm{c}}$ is the exergy consumption rate within the terminal unit [W], and $\mathrm{X}_{\text {out }}$ is the exergy supplied to indoors from the terminal unit [W], given by Eq. (5) for floor heating and by Eq. (6) for radiator heating, respectively. Eqs. (8) and (9) apply both for floor heating and radiator heating.

The exergy of the supply and return water flows are calculated as

$X_{w}=V_{w} c_{w} \rho_{w}\left\{\left(T_{w}-T_{o}\right)-T_{o} \ln \frac{T_{w}}{T_{o}}\right\}$

Where $X_{w}$ is the exergy of the water flow [W], $V_{w}$ is the volumetric flow rate of water $\left[\mathrm{m}^{3} / \mathrm{s}\right], \mathrm{c}_{\mathrm{W}}$ is the specific heat capacity of water $[\mathrm{J} / \mathrm{kgK}], \rho_{\mathrm{w}}$ is the density of water $\left[\mathrm{kg} / \mathrm{m}^{3}\right]$, and $\mathrm{T}_{\mathrm{w}}$ is the temperature of water $[\mathrm{K}]$.

The exergy consumption in the air-heating coil in the AHU is obtained as

$\Delta X_{w}-X_{c}=\Delta X_{a}$

$\Delta X_{w}=X_{w, \text { supply }}-X_{w, \text { return }}$

$\Delta X_{a}=X_{a, o u t}-X_{a, \text { in }}$

Where $\mathrm{X}_{\mathrm{w}, \text { supply }}$ is the exergy of the water entering the air-heating coil (from boiler) [W], $\mathrm{X}_{\mathrm{w}, \text { return }}$ is the exergy of the water leaving the air-heating coil (to boiler) [W], $\mathrm{X}_{\mathrm{a}, \text { out }}$ is the exergy of the air leaving the air-heating coil [W], and $\mathrm{X}_{\mathrm{a}, \text { in }}$ is the exergy of the air entering the air-heating coil [W]. The exergy of the water is calculated using Eq. (10). The exergy of the air is calculated using the following Eq. (14).

$X_{a}=V_{a} c_{a} \rho_{a}\left\{\left(T_{a}-T_{o}\right)-T_{o} \ln \frac{T_{a}}{T_{o}}\right\}$

Where $\mathrm{X}_{\mathrm{a}}$ is the exergy of the air flow $[\mathrm{W}], \mathrm{V}_{\mathrm{a}}$ is the volumetric flow rate of air $\left[\mathrm{m}^{3} / \mathrm{s}\right]$, and $\mathrm{T}_{\mathrm{a}}$ is the temperature of the air flow $[\mathrm{K}]$. 
The exergy consumption in the heat recovery unit is obtained through the exergy balance equation set up for the heat recovery device:

$X_{\text {outdoor air }}+X_{\text {exhaust air }}-X_{c}=X_{\text {inlet air }}+X_{\text {discharge air }}$

Where $\mathrm{X}_{\text {outdoor air }}$ is the exergy of the intake air from outdoors $(=0)[\mathrm{W}], \mathrm{X}_{\text {exhaust air }}$ is the exergy of the exhaust air (from the indoor space) [W], $\mathrm{X}_{\text {inlet air }}$ is the exergy of the inlet air (supply air for the floor heating and radiator heating cases, and the air entering the air-heating coil in the warm-air heating case with heat recovery) [W], and $\mathrm{X}_{\mathrm{discharge}}$ air is the exergy of the discharge air (discarded to the environment after the heat recovery) [W]. Eq. (14) is used for calculating $X_{\text {outdoor air }}, X_{\text {exhaust air }}, X_{\text {inlet air }}, X_{\text {discharge air }}$.

In addition to the exergy consumption due to heat transfer in the heat recovery device, the discharged air also contains a certain amount of exergy. This exergy is totally consumed while the discharged air is completely discarded into the environment.

3.5. Exergy input to the boiler and the power plant

The exergy input to the boiler is calculated using Eq. (16).

$X_{\text {in,boiler }}=\frac{Q_{\text {boiler }}}{\eta_{\text {boiler }}} r$

Where $\mathrm{X}_{\mathrm{in} \text {,boiler }}$ is the exergy input by natural gas to the boiler [W], $\mathrm{Q}_{\mathrm{boiler}}$ is the rate of heat to be provided by the boiler [W], $\eta_{\text {boiler }}$ is the boiler efficiency, and $\mathrm{r}$ is the ratio of chemical exergy to higher heating value of natural gas. Qboiler is $2180 \mathrm{~W}$ for the floor heating and radiator heating cases as described in 2.3, while for warm-air heating cases without and with heat recovery, it is $5460 \mathrm{~W}$ and $2559 \mathrm{~W}$, respectively, as described in 2.4.3. 
For the floor heating cases when a heat pump was used as the heat source, the exergy input required at the power plant was calculated as follows:

$E_{H P}=\frac{Q_{\text {heating }}}{C O P}$

$X_{\text {in,power plant }}=\frac{E_{H P}}{\eta_{T O T}} r$

Where $\mathrm{E}_{\mathrm{HP}}$ is power (electricity) input to the heat pump [W], COP is the coefficient of performance, $\mathrm{X}_{\mathrm{in}}$, power plant is the exergy input to the power plant through natural gas [W], $\eta_{\text {TOT }}$ is the total efficiency including conversion efficiency of the power plant, distribution and transmission efficiencies of the grid.

Exergy input required at the power plant for the pump and fans are calculated using Eq. (18) by replacing the $\mathrm{E}_{\mathrm{HP}}$ with respective pump power $\left(\mathrm{E}_{\text {pump }}\right)$ and fan power $\left(\mathrm{E}_{\mathrm{fans}}\right)$.

\section{Results and discussion}

\subsection{Comparison of different space heating systems}

The exergy inputs, outputs, and consumptions in different system components are shown in Fig. 4. The chains of exergy flows from the exergy input to the boiler to the environment are shown in Fig. 5. The exergy contained by natural gas is supplied to the boiler at a rate of $2253 \mathrm{~W}$, and the exergy output from the boiler to the water circulating in the floor is $300 \mathrm{~W}$ (FH_HiRes). The difference between the input and output exergy is the exergy consumption in the boiler (due to combustion and exhausted gas through the chimney). The same relationship between input, output and consumption applies also to other components. 

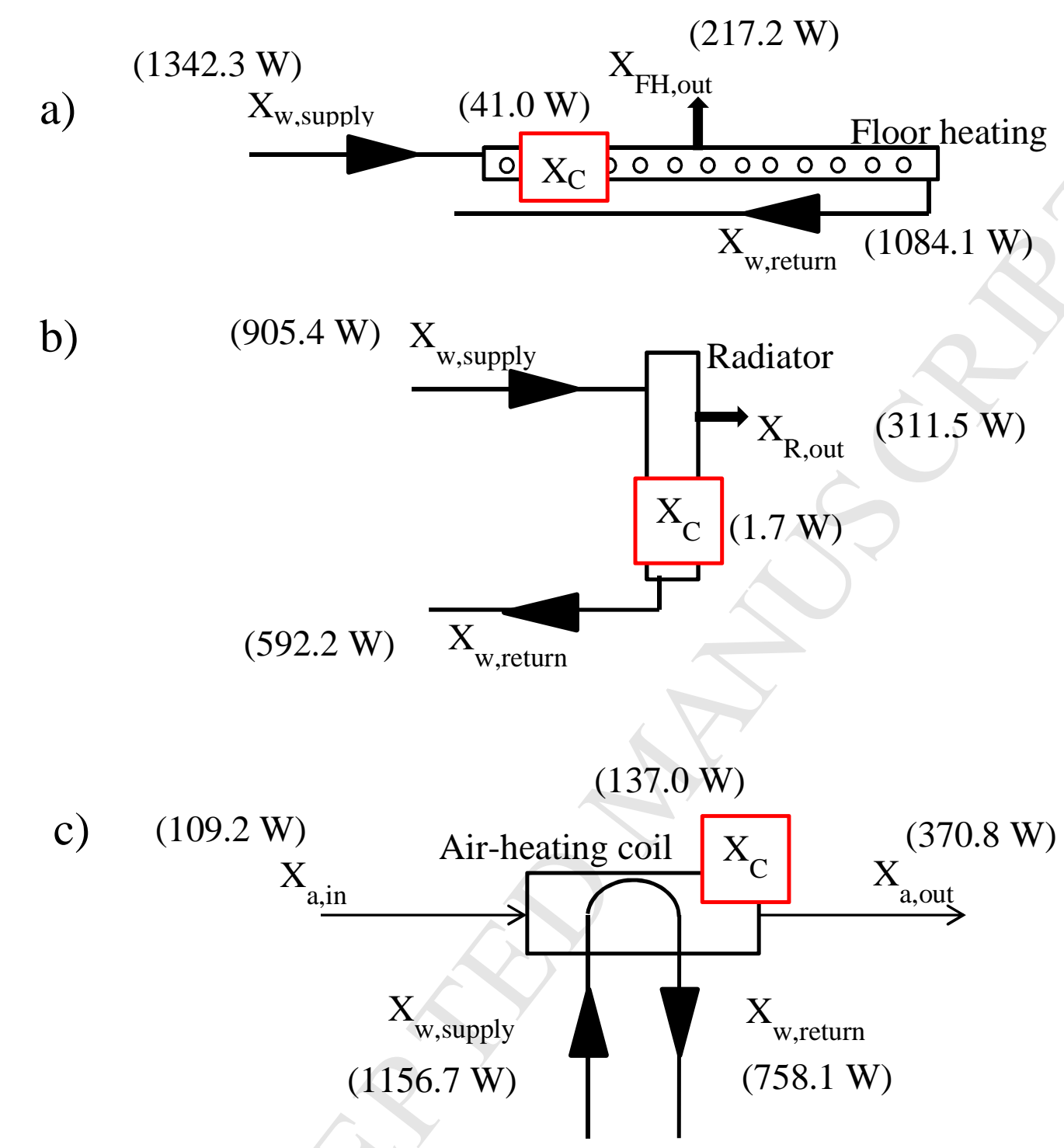

d)

Heat recovery device (cross-flow heat exchanger)

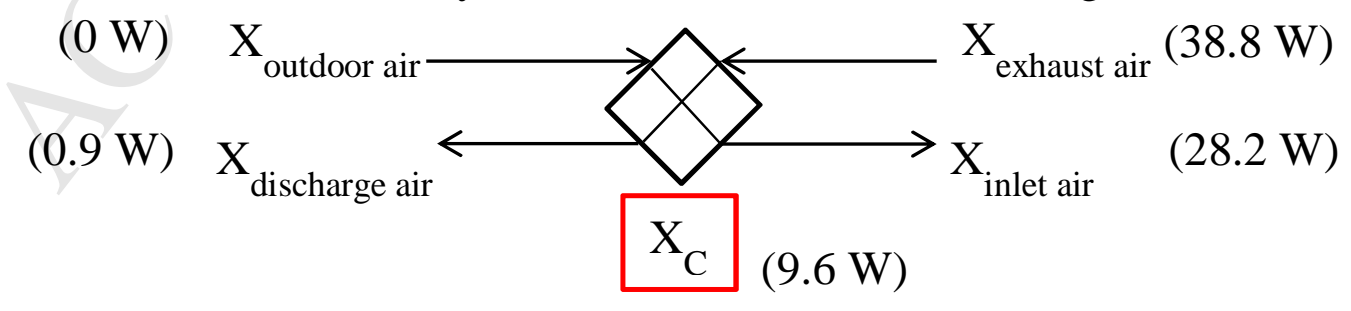

Fig. 4. Exergy input, output, and consumption in different system components: a) Floor (FH_LoRes) b) Radiator (R_45) c) Air-heating coil (WAH_HR) d) Heat recovery device ( 0.5 ach, floor heating and radiator cases). Values in the parentheses indicate the exergy values. 
a)

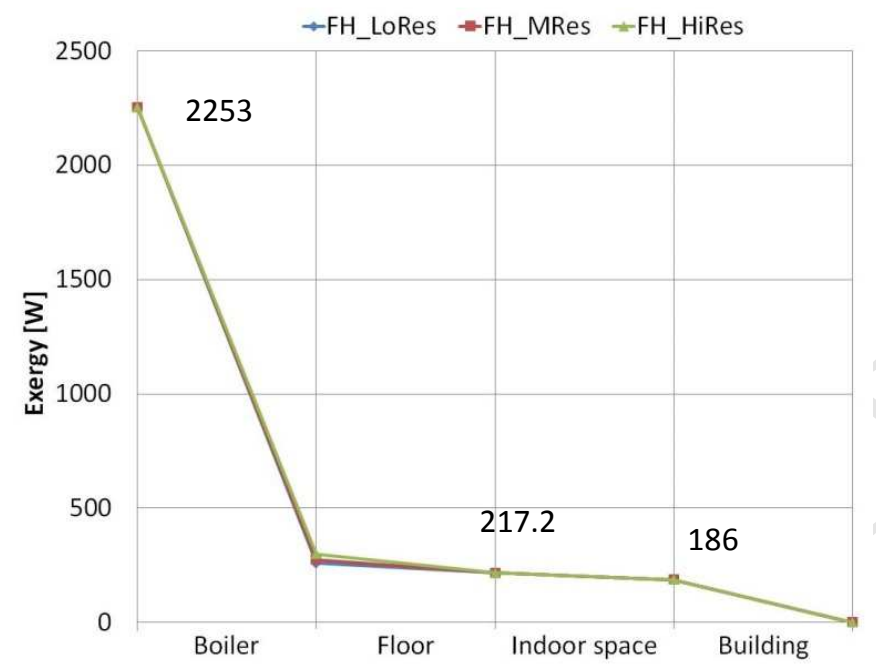

b)

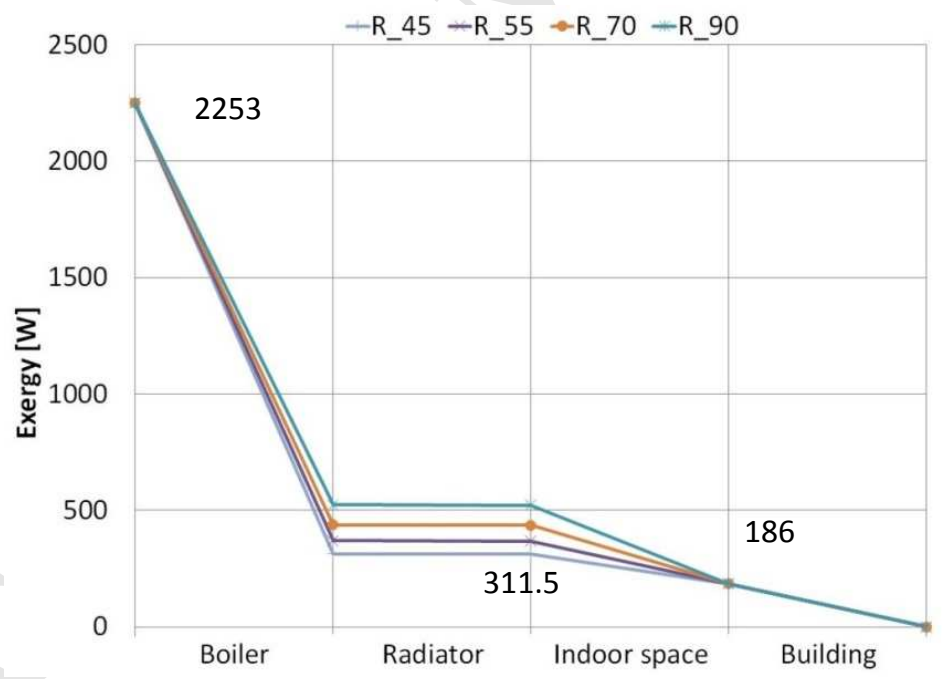


c)

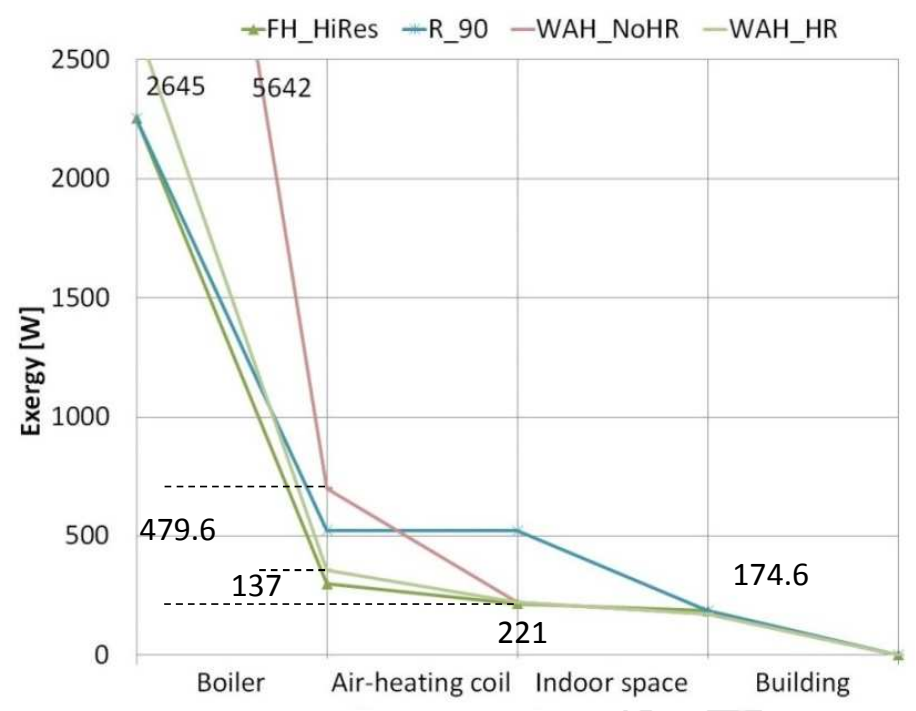

Fig. 5. Exergy flows for different heating strategies: a) Floor heating b) Radiator heating c) Warm-air heating

The heating exergy load [1] (input to the "Building" in Fig. 5) consists of the heat loss from the building envelope (transmission loss) and the heat required to bring the fresh air at $16.3^{\circ} \mathrm{C}$ to the indoor temperature of $20^{\circ} \mathrm{C}$, therefore the heating exergy loads are the same for the floor heating and radiator heating cases (186 W). In the warm-air heating case, this load is different $(174.6 \mathrm{~W})$ since the supply air has to be warmer than the indoor air.

Exergy consumption in the indoor space varies with different heating strategies. For the floor heating cases the exergy consumption in the space is $31.2 \mathrm{~W}$, and this is the smallest among all cases. This is because of the low temperature heating possibility and the low surface temperature of the floor. For the radiator cases, the exergy consumption in the indoor space increases with the increasing average water temperature. Among the four radiator cases, the smallest exergy consumption in the indoor space is $125.5 \mathrm{~W}$ for $\mathrm{R}_{-} 45$. Exergy consumption in the indoor space with the warm-air heating is $46.3 \mathrm{~W}$, which is between the values of floor heating $(31.2 \mathrm{~W})$ and radiator cases $(125.5 \mathrm{~W})$. Nonetheless, it should be noted that this is only in the indoor space and does not consider the rest of the systems. 
For different floor covering resistances, the energy coming into the floor structure (heat emitted to the indoor space) is the same but the exergy is different. The increased floor covering resistance results in higher average water temperature to obtain the same floor surface temperature to provide the necessary space heating. This inevitably results in increased exergy supply to and consumption within the floor structure. Compared to the low resistance case, in which $41 \mathrm{~W}$ is consumed, the exergy consumption increased by $42 \%$ and almost doubled for the cases with mid- and high floor covering resistances, respectively.

The exergy consumption within the radiators was very small, ranging from $1.2 \mathrm{~W}$ to $1.7 \mathrm{~W},(0.2 \%$ to $0.6 \%$ of net thermal exergy input to the radiators). This small exergy consumption was mainly due to the assumed surface temperature (due to the high conductivity of materials used for constructing radiators) of the radiators.

Fig. 5 shows that the largest exergy consumption in the terminal units (the air-heating coil for warm-air heating cases) occurred for the warm-air heating cases. The application of heat recovery on the exhaust air resulted in a significant decrease in the exergy consumption within the air-heating coil, from $479.6 \mathrm{~W}$ to $137 \mathrm{~W}$, because with heat recovery the air temperature should be increased from $16.3^{\circ} \mathrm{C}$ to $35^{\circ} \mathrm{C}$ in the air-heating coil compared to no heat recovery where the air temperature should be increased from $-5^{\circ} \mathrm{C}$ to $35^{\circ} \mathrm{C}$. This is also reflected in the necessary energy and exergy inputs to the boiler.

The floor heating and radiator cases require the same fuel (exergy) input to the boiler (2253 W) while the required fuel input is the largest for the warm-air heating without heat recovery $(5642 \mathrm{~W})$, followed by the case with warm-air heating with heat recovery $(2645 \mathrm{~W})$.

The results show that the floor heating system requires the smallest exergy input to provide the same space heating. Higher floor covering resistance hinders the performance of the floor heating system. When comparing the cases with the lowest and highest floor covering resistances, the exergy consumption in the floor structure doubles and the required exergy input to the floor structure increases by $16 \%$ with a higher floor covering 
resistance. This underlines the importance of keeping the floor covering resistance to a minimum through selection of floor covering material and thickness to fully benefit from a low temperature heating system.

The radiator and warm-air heating cases have remarkably higher exergy demand compared to floor heating cases. The floor heating system with the highest floor covering resistance and the radiator with lowest average water temperature require relatively close exergy inputs ( $300 \mathrm{~W}$ and $313 \mathrm{~W}$, respectively) although the floor heating system still requires lower exergy input. Among the investigated cases, the floor heating performed better than other space heating systems, in terms of required exergy input, and exergy consumption.

Regarding the exergy inputs to the heating plant, it can be observed that the use of a boiler does not allow taking advantage of the low exergy demand of the radiant floor heating system. The largest exergy consumption through the whole space heating process occurs in the boiler and this is mainly due to the combustion process inside the boiler.

Due to this mismatch of supply (high) and demand (low) exergy levels, an air-source heat pump was assumed to replace the condensing boiler to be the focus in the following analyses.

4.2.Comparison of the effects of different floor covering resistances on heat pump performance

The exergy flows for the whole process of space heating using a heat pump is shown in Fig. 6. 


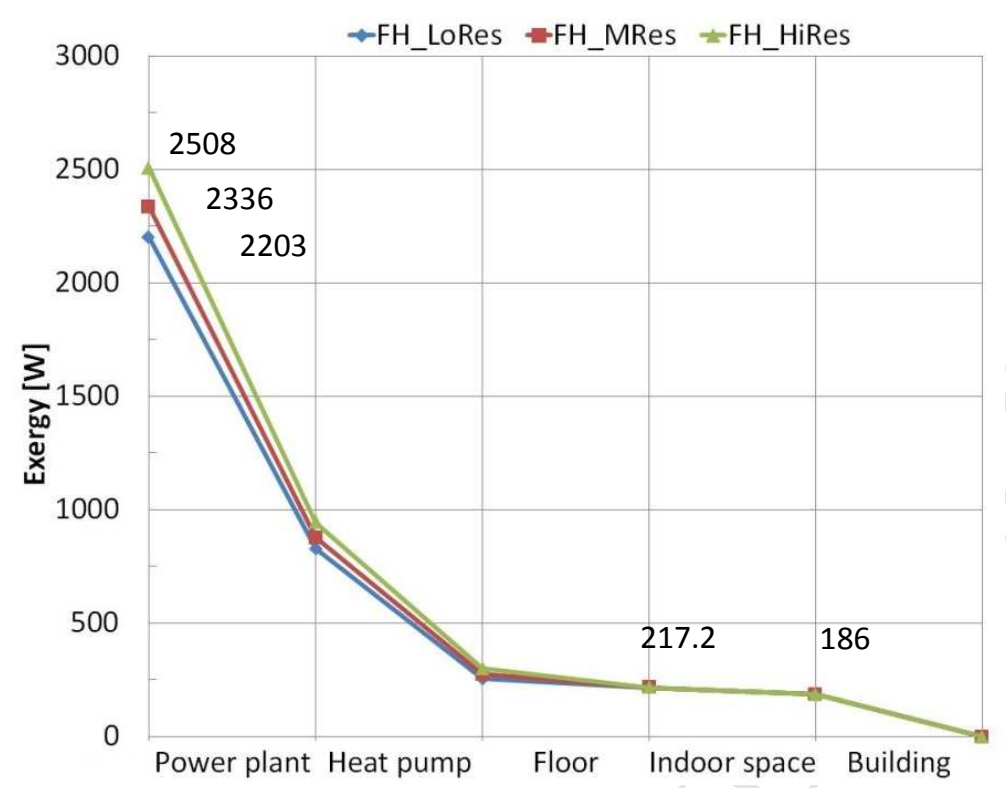

Fig. 6. Exergy flows for the floor structures with different floor covering resistances

Fig. 6 shows that in order to obtain the same space heating effect, higher electricity input is required to the heat pump with increased floor covering resistance. This means that a higher exergy input is necessary to the power plant where the electricity is generated. This system behavior is because a higher floor covering resistance requires higher average water temperature for the floor heating system, which leads to a higher condensing temperature for the heat pump, decreasing the heat pump performance (lowering the COP), as given in Table 3 .

When the overall exergy inputs to the boiler and to the power plant are compared, the results show that the use of a heat pump instead of a boiler is beneficial only when the floor covering resistance is kept to a minimum (FH_LoRes). For FH_MRes and FH_HiRes, the use of a boiler is a better choice, as far as the present cases are concerned. These results indicate that further considerations are necessary regarding different heat sources.

The results suggest that the improved COP and lowered floor covering resistance has similar effects on the whole system performance, i.e. improvement with the same thickness (or material) is comparable to an improvement in the heat pump COP. 
The results also show that the increased floor covering resistance has a similar effect on the heating plant (waterside of the radiant floor heating system) to an increase in heating load, although the space heating load itself is in fact constant; to obtain the same space heating effect, higher electricity input is required to the heat pump, and 14\% higher exergy input is necessary to the power plant for FH_HiRes compared to FH_LoRes.

\subsection{The effects of the heat source}

The comparison of the boiler and the heat pump showed that there is a critical COP value ( 2.57 for the present calculations) for a heat pump, and the COP should be greater than this value for the heat pump to be beneficial over the boiler. This finding agrees with Kilkis [35] that it is crucial to consider and account for the source of the electricity used for the heat pump (generation plant, fuel input to the plant, distance to the utilization site, etc.).

In order to achieve a higher system performance, the improvement could be either on the power plant (higher conversion efficiency, on-site generated renewable electricity, etc.) or on the performance of the heat pump; increased COP through a better heat pump, by using a heat pump which is coupled to another heat source, such as ground, lake water, sea water, etc. Recent studies [5], [36] showed that an air-source heat pump does not benefit from any heat source (ambient air does not contain any exergy as opposed to other heat sources and sinks which contain exergy), and it is basically a machine to separate the exergy (electricity) into cool and warm exergy.

In order to make a true use of the sustainable energy resources (ground, lake, sea, etc.), the first priority is to minimize the heating and cooling demands of the building. Such minimization would allow the use of a broad range of heat sources and sinks. With a high heating and cooling demand, the exergy demand necessarily becomes higher and it narrows the range of heat sources and sinks that can be used so the use of low-exergy ones becomes limited and the use of mid- to high-exergy content resources becomes inevitable. 
Depending on the geographical availability, biomass or other sustainable fuels could be used in a boiler. To sustain such an operation, a prerequisite is to decrease the heating (or cooling) demand of the building as much as possible.

\subsection{Auxiliary energy input, and heat recovery in the AHU}

In addition to the thermal exergy analyses, the effects of electricity inputs to pumps and fans on the whole exergy consumption patterns were also considered. The results are presented in Fig. 7.

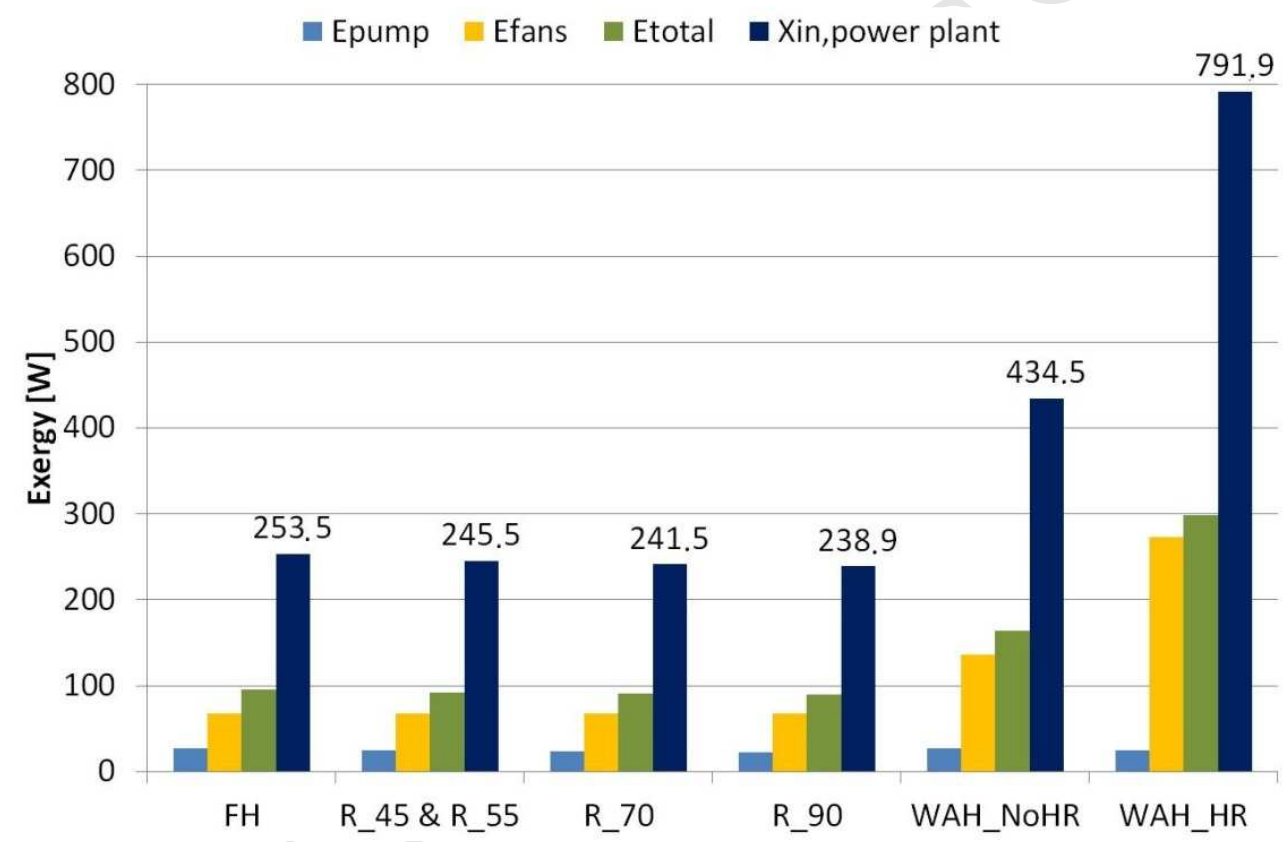

Fig. 7. Required exergy inputs to the pump, fans and to the power plant (four bars in each case indicate, from left to right, the exergy input to pump, to fans, their total, and the exergy input to the power plant)

The floor heating cases require the largest pumping power due to the smallest temperature drop between the supply and return water flows among the investigated cases. When taking the pumping power into account, the overall performances of the floor heating case with the highest floor covering resistance, FH_HiRes, and the radiator with the lowest average water temperature, $R_{-} 45$, became close although the floor heating case still requires $5 \mathrm{~W}$ lower exergy input (300 and $313 \mathrm{~W}$ thermal exergy, and 253.5 and $245.5 \mathrm{~W}$ exergy for auxiliary 
components for FH_HiRes and R_45, respectively). A difference of $5 \mathrm{~W}$ might not seem significant from the energy viewpoint (thermal energy load is in the order of $10^{2}$ to $10^{3}$ ) but from the exergy viewpoint, it is significant. Considering radiative exergy emission and absorption, magnitudes of $\mathrm{mW}$ (in the order of $10^{-3}$ ) can make a difference in the perception of the thermal environment [5], therefore a difference of $5 \mathrm{~W}$ exergy is not negligible and presents an advantage over the radiator solution.

The results also show that an air-based heating system requires large fan powers, resulting in a further decrease of the energy and exergy performance. This is mainly because larger flow rates and volumes are required to transport the same amount of heat with air compared to water-based systems and this emphasizes an advantage of water-based heating and cooling systems over air-based systems.

In the current study and in actual house design [24], [26], the indoor space was mainly heated and cooled by the radiant floor heating and cooling system and the ventilation system was only used to provide the required amount of fresh air. When considering the pump and fan consumptions together with the thermal exergy values presented previously in 4.1 , this approach proved to be an efficient approach.

The analyses showed that to fully benefit from the low-exergy potential of low temperature heating and high temperature cooling systems, the dimensioning of the auxiliary components (fans, pumps, valves, dampers, and so forth) should be carried out carefully. It is crucial to minimize the exergy demand of these components; especially for systems with a low temperature difference between the supply and return flows. This becomes clearer in terms of exergy: for the floor heating cases, the energy supplied to the pump is $1.3 \%$ of the heat provided from the floor to the indoor space while the exergy input to the pump is $12.7 \%$ of the exergy supplied from the floor to the indoor space (27.5 W pump power vs. $2180 \mathrm{~W}$ space heating load and $217.2 \mathrm{~W}$ exergy supplied from the floor to the indoor space, respectively).

There is a trade-off between the exergy gain with the heat recovery unit and the electricity necessarily supplied to the additional exhaust fan (also the extra fan power needed to cover the additional pressure drops). Depending 
on the local climate, ventilation rate and also on the efficiency of the heat recovery unit, it might not always be beneficial to have heat recovery. If the exergy input to the fan exceeds the exergy recovered from the exhaust air, this indicates that there is a threshold for which the heat recovery is beneficial. This issue should be carefully considered before applying heat recovery on ventilation systems.

When considering the warm-air heating cases without and with heat recovery, extra exergy input for the added exhaust fan is the crucial parameter to consider when evaluating the benefits of heat recovery. The extra exergy input required at the power plant for the additional fan in the case of warm-air heating with heat recovery is $357.4 \mathrm{~W}$ which is significantly less than the saved exergy input to the boiler due to the application of heat recovery $(2998 \mathrm{~W})$, therefore the application of heat recovery is justified for this case.

During the heat recovery from the exhaust air, the exergy consumption in the heat recovery unit is inevitable. Due to heat transfer between air streams, there is exergy consumption in the heat recovery unit and also due to the efficiency being less than $100 \%$ (exergy is necessarily consumed even if the $100 \%$ energy-wise efficiency is possible), it is not possible to fully recover the thermal exergy from the exhaust air. A certain amount of air with exergy is being discarded into the environment after the heat recovery, and hence it is lost. This amount of exergy would vary in different locations: in the present case of Denmark, due to low outdoor temperature, it has higher exergy compared to another location with a mild climate.

The exergy consumption in the heat recovery unit for the warm-air heating case is $37.2 \mathrm{~W}$ ( $40.6 \mathrm{~W}$ including the exergy of the discharge air), and for the floor heating and radiator cases is $9.6 \mathrm{~W}$ (10.5 W including the exergy of the discharge air).

\subsection{Overall discussion}

Although the heat losses from the distribution and emission systems were not considered in this study, heat losses should be minimized for high energy- and exergy-wise performance of heating systems. 
The choice of the terminal unit has a direct and significant effect on the thermal comfort of occupants. The radiant low temperature heating and high temperature cooling systems (floor, ceiling, and wall heating or cooling) perform better than other room conditioning systems in terms of providing a thermally comfortable indoor environment due to their advantages of minimizing the risk of unpleasant air movement, and of creating a uniform thermal indoor environment [37], [38].

Heat source and terminal unit selection would depend on the available products, costs, location of the building (connection to a district heating network, regulations regarding use of the ground, etc.), additionally, pressure drops would also change depending on the piping lay-out. Pressure drops will affect the necessary pumping powers. Given the overall possibilities and limitations of system selection, to achieve exergy-efficiency, the system and all its components should be considered as a whole from the beginning of the design process. It is crucial to minimize the demand of the building; this would enable to use a broad range of heat sources (ground, lake, etc. especially those to be found in our surroundings), among the available heat sources, the most environmentally friendly and sustainable heat source should be chosen to meet the exergy demand of the building.

\section{Conclusion}

Exergy performances of different space heating systems (floor heating, radiator heating, and warm-air heating) were compared in this study. In addition to the thermal exergy, these systems were also compared in terms of auxiliary exergy used for pumps and fans. The relative benefits of applying heat recovery on the ventilation system were also studied.

For the floor heating systems, the effects of floor covering resistance on the whole system performance was studied, and two heat sources were compared; a natural gas fired condensing boiler and an air-source heat pump.

The main conclusions from the analyses are as follows: 
1. Among the investigated cases, the floor heating system had the lowest exergy consumption and it performed better than other space heating systems in terms of required exergy input, and exergy consumption.

2. Coupling of a natural gas fired condensing boiler with the floor heating system is not an efficient strategy due to the mismatch of the exergy supply and demand. Therefore it does not allow taking advantage of the low exergy demand of the radiant floor heating system.

3. Using a heat pump instead of a boiler as the heat source could provide a better match for the low exergy demand of the floor heating system, but there is a critical COP value and only above this COP value it is beneficial to use a heat pump instead of a boiler. It is also crucial to account for the source of electricity supplied to the heat pump (e.g. generated at a remote, fossil fuel power plant or at a nearby renewable energy plant).

4. Subjective choices on floor covering have significant effects on the performance of the floor heating system and on the whole system. Higher floor covering resistance hinders the performance of the whole system. When comparing the cases with the lowest and highest floor covering resistances, the exergy consumption in the floor structure doubles and the required exergy input to the floor structure increases by $16 \%$ with a higher floor covering resistance. This means that to obtain the same space heating effect, higher electricity input is required to the heat pump, and $14 \%$ higher exergy input is necessary to the power plant where the electricity is generated.

In order not to hinder the performance of a radiant system (floor heating, floor cooling, ceiling cooling and so forth), the covering resistance should be kept to a minimum, providing that structural and maintenance (e.g. wear and tear on floor coverings) concerns can be met and that the occupants are aesthetically satisfied.

5. The present analyses showed that the water-based systems require lower auxiliary energy use than the air-based heating system. This is a clear benefit of water-based systems over air-based systems. To fully benefit from the low-exergy heating potential of the low temperature heating systems, the dimensioning 
and choice of the auxiliary components should be made carefully and this is clearly explained with the exergy analyses.

6. For a heat recovery unit to be beneficial, the thermal exergy gained from the heat recovery (from the exhaust air) must be greater than the exergy supplied to the exhaust fan, and this analysis should be carried out before deciding on the application of heat recovery. In the current analyses the application of heat recovery proved to be beneficial: the extra exergy input required at the power plant for the additional fan in the case of warm-air heating with heat recovery was $357.4 \mathrm{~W}$ which is significantly smaller than the reduced exergy input to the boiler due to the application of heat recovery ( $2998 \mathrm{~W})$.

\section{Acknowledgments}

This study was financially supported by the Danish Energy Association's Research and Development Program (ELFORSK), project no. 344-060, "Sustainable plus-energy houses". The financial supports from DANVAK (Danish HVAC Society), Otto Mønsteds Fond, and Augustinus Fonden for an external research stay at the Tokyo City University are gratefully acknowledged. The authors thank Associate Prof. Dr. Jørn Toftum for his comments and help in editing the manuscript of this article.

\section{References}

[1] M. Shukuya, "Energy, entropy, exergy and space heating systems," in Healthy Buildings '94, Proceedings of the 3rd International Conference, Budapest, 1994.

[2] M. Dovjak, M. Shukuya, B. W. Olesen and A. Krainer, "Analysis on exergy consumption patterns for space heating in Slovenian buildings," Energy Policy, pp. 2998-3007, 2010.

[3] A. Yildiz and A. Gungor, "Energy and exergy analyses of space heating in buildings," Applied Energy, pp. 
1939-1948, 2009.

[4] M. Shukuya, "Exergy concept and its application to the built environment," Building and Environment, pp. 1545-1550, 2009.

[5] M. Shukuya, Exergy - Theory and Applications in the Built Environment, New York: Springer, 2013.

[6] D. Schmidt, "Low exergy systems for high-performance buildings and communities," Energy and Buildings, pp. 331-336, 2009.

[7] A. Hepbasli, "Low exergy (LowEx) heating and cooling systems for sustainable buildings and socities," Renewable and Sustainable Energy Reviews, pp. 73-104, 2012.

[8] F. Meggers, V. Ritter, P. Goffin, M. Baetschmann and H. Leibundgut, "Low exergy building systems implementation," Energy, vol. 41, no. 1, pp. 48-55, 2012.

[9] B. Fan, X. Jin, X. Fang and Z. Du, "The method of evaluating operation performance of HVAC system based on exergy analysis," Energy and Buildings, vol. 77, p. 332-342, 2014.

[10] Z. Du, X. Jin and B. Fan, "Evaluation of operation and control in HVAC (heating, ventilation and air conditioning) system using exergy analysis method," Energy, vol. 89, pp. 372-381, 2015.

[11] M. Razmara, M. Maasoumy, M. Shahbakhti and R. D. Robinett III, "Optimal exergy control of building HVAC system," Applied Energy, vol. 156, p. 555-565, 2015.

[12] P. Gonçalves, A. R. Gaspar and M. G. da Silva, "Comparative energy and exergy performance of heating options in buildings under different climatic conditions," Energy and Buildings, vol. 61, p. 288-297, 2013. 
[13] Y. Zhou and G. Gong, "Exergy analysis of the building heating and cooling system from the power plant to the building envelop with hourly variable reference state," Energy and Buildings, vol. 56, pp. 94-99, 2013.

[14] M. T. Balta, I. Dincer and A. Hepbasli, "Performance and sustainability assessment of energy options for building HVAC applications," Energy and Buildings, p. 1320-1328, 2010.

[15] S. P. Lohani, "Energy and exergy analysis of fossil plant and heat pump building heating system at two different dead-state temperatures," Energy, pp. 3323-3331, 2010.

[16] S. P. Lohani and D. Schmidt, "Comparison of energy and exergy analysis of fossil plant, ground and air source heat pump building heating system," Renewable Energy, pp. 1275-1282, 2010.

[17] R. Zmeureanu and X. Y. Wu, "Energy and exergy performance of residential heating systems with separate mechanical ventilation," Energy, pp. 187-195, 2007.

[18] D. Schmidt, "Benchmarking of low 'exergy' buildings," International Journal of Exergy, pp. 473-480, 2012.

[19] B. Kilkis, "Enhancement of heat pump performance using radiant floor heating systems," in AES-Vol. 28, Recent Research in Heat Pump Design, Analysis, and Application, Anaheim, 1992.

[20] P. Simmonds, N. Triana, J. Gautrey and R. Zhu, "The Influence on Surface Coverings on the Performance of Radiant Floors for both Heating and Cooling," in ASHRAE Papers CD: 2014 ASHRAE Winter Conference, Atlanta, 2014.

[21] S. Sattari and B. Farhanieh, "A parametric study on radiant floor heating system performance," Renewable Energy, pp. 1617-1626, 2006.

[22] B. W. Olesen, "Using Building Mass To Heat and Cool," ASHRAE Journal, pp. 44-52, 2012. 
[23] The Danish Ministry of Economic and Business Affairs, "The Building Regulations 2010," The Danish Ministry of Economic and Business Affairs, Danish Enterprise and Construction Authority, Copenhagen, 2010.

[24] O. B. Kazanci, M. Skrupskelis, P. Sevela, G. K. Pavlov and B. W. Olesen, "Sustainable Heating, Cooling and Ventilation of a Plus-Energy House via Photovoltaic/Thermal Panels," Energy and Buildings 83, pp. 122-129, 2014.

[25] M. Skrupskelis and O. B. Kazanci, "Solar sustainable heating, cooling and ventilation of a net zero energy house," Technical University of Denmark, Kgs. Lyngby, 2012.

[26] O. B. Kazanci and B. W. Olesen, "Sustainable Plus-energy Houses: Final Report," Technical University of Denmark, Department of Civil Engineering, Kgs. Lyngby, 2014.

[27] DS 469, 2nd edition, "Heating- and cooling systems in buildings," Danish Standards, Charlottenlund, 2013.

[28] B. W. Olesen, E. Mortensen, J. Thorshauge and B. Berg-Munch, "Thermal comfort in a room heated by different methods," ASHRAE Transactions, pp. 34-47, 1980.

[29] EN 1264-2, "Water based surface embedded heating and cooling systems - Part 2: Floor heating: Prove methods for determination of the thermal output using calculation and test methods," European Committee for Standardization, Brussels, 2008.

[30] J. Babiak, B. W. Olesen and D. Petráš, Low temperature heating and high temperature cooling, Brussels: REHVA - Federation of European Heating, Ventilation and Air Conditioning Associations, 2009.

[31] EN 1264-3, "Water based surface embedded heating and cooling systems - Part 3: Dimensioning," 
European Committee for Standardization, Brussels, 2009.

[32] ASHRAE Handbook, HVAC Systems and Equipment, Atlanta: American Society of Heating, Refrigerating and Air-Conditioning Engineers, 2000.

[33] prEN 15316-2, "Energy performance of buildings, modules M3-5, M4-5 - Space emission systems (heating and cooling)," European Committee for Standardization, Brussels, 2014.

[34] EN 13779, "Ventilation for non-residential buildings - Performance requirements for ventilation and roomconditioning systems," European Committee for Standardization, Brussels, 2007.

[35] B. Kilkis, "Exergy metrication of radiant panel heating and cooling with heat pumps," Energy Conversion and Management, pp. 218-224, 2012.

[36] R. Li, R. Ooka and M. Shukuya, "Theoretical analysis on ground source heat pump and air source heat pump systems by the concepts of cool and warm exergy," Energy and Buildings, pp. 447-455, 2014.

[37] B. Olesen, "Radiant Floor Cooling Systems," ASHRAE Journal, pp. 16-22, 2008.

[38] K.-N. Rhee and K. W. Kim, "A 50 year review of basic and applied research in radiant heating and cooling systems for the built environment," Building and Environment, pp. 166-190, 2015. 


\section{Highlights}

- Exergy performances of different space heating systems were compared.

- Floor heating had lower exergy demand and consumption compared to other systems.

- Using a boiler with floor heating creates a mismatch in exergy supply and demand.

- The source of electricity to a heat pump should be considered when comparing it with a boiler.

- Floor covering resistance should be minimized to fully benefit from low temperature heating. 